\title{
KERAGAAN MODEL KEBIJAKAN PEMBANGUNAN EKONOMI SEKTOR IMMT DI SUMATERA UTARA
}

\author{
Eko Wahyu Nugrahadi \\ Indra Maipita \\ Chandra Situmeang \\ Fakultas Ekonomi Universitas Negeri Medan \\ Jl. Williem Is kandar Ps. V Medan 20221, Telp. 061-6613365 \\ Email: ewahyunugrahadi@yahoo.com, imaipita@gmail.com, \\ chandarsitumeang@gmail.com
}

\begin{abstract}
Economic growth in North Sumatera (Sumut) in the last five years has increased significantly. However, income inequality be widened. From the results of previous research has identified that one of the six sectors that have the most optimal possibilities for development as the development model of economic development of sectoral policies that can solve that problem in Sumut is the industry of food, beverages and tobacco (IMMT). The question needs further analysis to obtain a more in-depth information in the development of that sector. Specifically, this study aims to identify the body of model of economic development policy in IMMT sector in addressing income inequality in the province of Sumut. The analysis is based on a model approach Social Accounting Matrix (SAM). For the purposes of analysis: (1) linkage, and (2) multiplier. Results of the analysis showed that IMMT have: (1) the index of sensitivityand power of dispersionis greater than one at a time, (2) forward and backward spread effect index larger than other sectors, (3) the second largest output multipliers, and (4) ranked sixth refers to the total sector.
\end{abstract}

Keywords: leading sector; Industrial Eat, Beverages and Tobacco (IMMT); and behousehold income inequality between groups

QE Journal | Vol.04 - No.02 June 2015 - 63 


\section{PENDAHULUAN}

encapaian pertumbuhan ekonomi (growth) yang tinggi merupakan
target utama yang lazimnya akan diupayakan dalam suatu
perekonomian guna mewujudkan masyarakat yang adil dan sejahtera.Pertumbuhan ekonomi Sumatera Utara yang diukur dari Produk Domestik Regional Bruto (PDRB) atas dasar harga konstan tahun 2000, dari tahun 2010 sampai dengan tahun 2014 mengalami kenaikan yang cukup signifikan(Gambar 1).Dalam kurun waktu 5 tahuntersebut rata-rata pertumbuhan Sumut sebesar 6,11 \%. Hal ini mengindikasikan bahwa kesejahteraan masyarakat Sumatera Utara lebih meningkat. Terlebih bila dikaitkan dengan keadaan jumlah penduduk miskin di daerah ini dalama kurun waktu tersebut menurun dari 11,31 \% (2010) menjadi 10,39\% (2013).

Meski jumlah dan persentase penduduk miskin dari waktu ke waktu mengalami penurunan namun dengan angka kemiskinan di tahun akhir pengamatan sebesar 1.416.400 jiwa atau sekitar 11,39 persen penduduk miskin di Sumatera Utara dinilai masih terlalu tinggi.

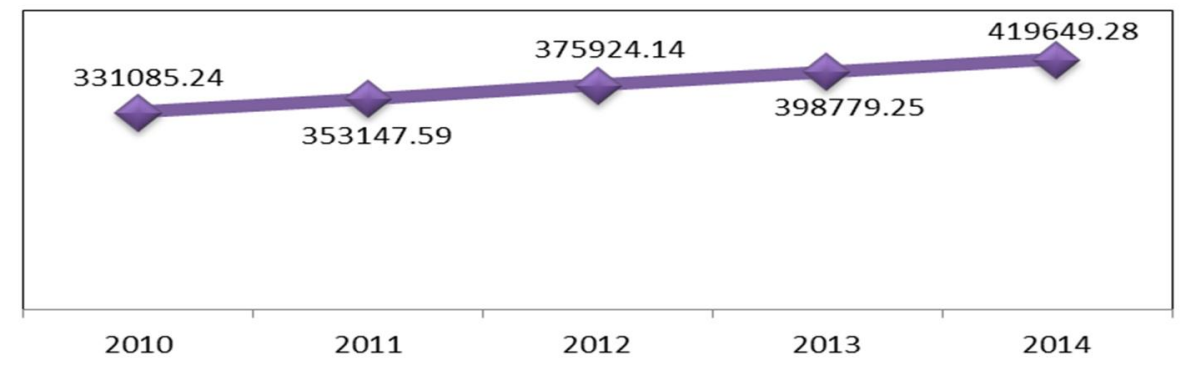

Sumber : BPS, 2010-2014

Gambar 1. Produk Domestik Regional Bruto Sumatera Utara (dalam Milyar Rupiah)

Salah satu akar permasalahan kemiskinan di Indonesia, khususnya Sumatera Utara adalah tingginya disparitas akibat tidak meratanya distribusi pendapatan antar golongan rumahtangga, sehingga kesenjangan antara golongan rumahtangga kaya dan rumahtangga miskin semakin melebar. Salah satu ukuran dalam menetapkan ketimpangan pendapatan rumahtangga tersebut adalah indeks Gini Rasio. 
Selama kurun waktu 2010-2013 perkembangan Indeks Gini Rasio Sumatera Utara mengalami peningkatan (dari 0,350 tahun 2010 menjadi 0,354 tahun 2014) sehingga ketimpangan pendapatan antar golongan rumahtangga di Sumatera Utara cenderung mengalami peningkatan. Selain itu besaran Gini Rasio tersebut menunjukkan bahwa pada kurun waktu tersebut kondisi ketimpangan pendapatan antar golongan rumahtangga relatif tinggi. Dengan demikian pertumbuhan ekonomi Sumatara Utara yang tinggi dan kecenderungan mengalami peningkatan tidak sepenuhnya dinikmati oleh seluruh lapisan masyarakat, sehingga mengarah pada terciptanya gap pendapatan antar golongan rumahtangga dan kemiskinan. Dengan demikian ukuran hasil dari pembangunan ekonomi tidak dapat hanya dicerminkan oleh tingginya pertumbuhan ekonomi dan besarnya pendapatan daerah, namun mencakup juga diantara hal hal berikut yang terkait dengan pembangunan manusia: ketimpangan pendapatan, jumlah penduduk miskin dan pengangguran. Oleh karena itu, dalam merancang strategi pembangunan ekonomi agar tidak hanya ditujukan pada pertumbuhan ekonomi (growth), akan tetapi juga perlu diikuti oleh membaiknya selain menurunnya jumlah penduduk miskin dan mengurangi pengangguran juga mengenai distribusi pendapatan.

Sebagaimana dinyatakan Todaro (2000 \&2011) bahwa proses pembangunan harus mampu membawa umat manusia melampaui pengutamaan materi dan aspek-aspek keuangan dari kehidupannya sehari-hari. Oleh karena itu ukuran hasil dari pembangunan ekonomi tidak dapat hanya dicerminkan oleh tingginya pertumbuhan ekonomi dan pendapatan nasional, namun mencakup juga bagaimana dapat mengatasi ketimpangan pendapatan. Masalah ketimpangan pendapatan, yang sering disebut pula kesenjangan, baik itu antara individu, rumah tangga, kelompok, sektor maupun wilayah, merupakan masalah yang selalu ada di setiap negara, tidak terkecuali di Sumut.

Untuk memahami peran sektor ekonomi dan kaitannya dengan distribusi pendapatan dapat dilakukan melalui alat analisis yang termasuk dalam teori kesimbangan umum.Terdapat model-model keseimbangan umum yang dapat digunakan dalam mempersiapkan rencana pembangunan ekonomi. Jhingan (2003) menyatakan bahwa salah satu jenis model perencanaan tersebut adalah model Input-Output (IO). Nazara (1997) menyatakan bahwa selain IO, alat analisis lain yang dikembangkan bagi 
perencanaan ekonomi adalah Sistem Neraca Sosial Ekonomi (SNSE) atau disebut sebagai Social Accounting Matrix (SAM).

Model SAM merupakan perluasan dari model IO, dimana model ini memotret perekonomian pada suatu waktu tertentu. Ruang lingkup model SAM jauh lebih luas dan terperinci dibandingkan dengan model IO. Model IO hanya menyajikan arus transaksi ekonomi dari sektor produksi ke sektor faktor produksi, rumahtangga, pemerintah, perusahaan dan luar negeri, sedangkan dalam model SAM, hal-hal tersebut di disagregasi secara lebih rinci. Sama halnya dengan model IO, model SAM juga merupakan sebuah matriks bujursangkar yang terdiri atas kolom dan baris. Kolom menjelaskan transaksi pengeluaran dan baris menjelaskan transaksi penerimaan. Total nilai transaksi pada kolom harus sama dengan total nilai transaksi pada baris agar syarat keseimbangan terpenuhi (Sadoulet dan de Janvry, 1995).Ada enam tipe neraca dalam model SAM (Thorbecke, 2001), yakni neraca: aktivitas produksi, komoditas, faktor produki (tenaga kerja dan kapital), institusi domestik (rumahtangga, perusahaan dan pemerintah), modal dan rest of the world.

Studi yang terkait dengan kebijakan pembangunan ekonomi sektoral dan bagaimana dampaknya secara terintegrasi dalam mengatasi masalah ketimpangan pendapatan antar golongan rumahtangga, kemiskinan dan pengangguran, khususnya menggunakan pendekatan SAM,sudah pernah dilakukan, diantaranya oleh Arndt et.al. (1998), Bautista et.al.(1999), Hafrizianda (2007) dan Nugrahadi (2007 dan 2008), namun penelitiannya dilakukan di tempat lain dan analisisnya hanya mencakup aspek makro belum dilakukan secara mikro. Untuk studi di daerah Sumatera Utara(Sumut) telah dilakukan oleh Nugrahadi (2007) tetapi masih terbatas pada kaitannya antara kebijakan ekonomi pembangunan secara sektoral dan dampaknya terhadap kemiskinan dan penyerapan tenaga kerja di Sumut.

Kemudian Nugrahadi (2013) juga telah melakukan studi lebih lanjut terkait dengan kebijakan pembangunan ekonomi secara sektoral di Sumut. Dari penelitian tersebut diketahuihasil, yaitu terdapat enam sektor merupakan leading sector, salah satunya adalah Industri Makanan, Minuman dan Tembakau (IMMT). Pertanyaannyabagaimana keragaan model pembangunan ekonomi sektor IMMTdi Sumatera Utara?. Sesuai dengan masalah yang diajukan, secara khusus tujuan penelitian ini untuk 
mengetahui keragaan pembangunan ekonomi sektor IMMT dalam mengatasi ketimpangan pendapatan antar golongan rumahtangga.

\section{METODE PENELITIAN}

Metode penelitian menggunakan analisis model SAM, untuk mendapatan gambaran keragaan model pembangunan ekonomi sektor IMMT. Terkait dengan metode analisis ini, diperlukan data SAM atau data Sistem Neraca Sosial Ekonomi (SNSE). Sehubungan data SAM Propinsi Sumatera Utara yang tersedia adalah publikasi tahun 1999, oleh karena itu dalam penelitian ini dibangun tabel SAM Tahun 2009. Untuk mendapatkan SAM tersebut dan sekaligusmendisagregasi secara lebih rinci dapat dilakukan dengan metode RAS dan Cross-Entropy (CE). Untuk kepentingan analisis data SNSE Provinsi Sumatera Utara selanjutnya diklasifikasi dalam 53 sektor sebagaimana terlihat pada Tabel 1. (lampiran).

Untuk memperoleh jawaban tujuan penelitian dilakukan analisis berdasarkan pendekatan model SAM. Untuk ke perluan ini dilakukan analisis: (1) keterkaitan dan (2) pengganda (multiplier). Kedua analisis yang digunakan dalam studi ini merujuk dari konsep yang telah dikemukakan Isard et.al. (1998).

Analisis keterkaitan digunakan untuk mengetahui besarnya tingkat keterkaitan suatu sektor terhadap lainnya. Analisis keterkaitan dalam studi ini didasarkan atas kriteriaRasmussen's dual(Daryanto, 1995). Kriteria ini meliputi pengukuran indeks berdasarkan, pertama, kepekaan penyebaran (sensitivity of dispersion) dan daya penyebaran (power dispersion), dan kedua, efek keluasan ke depan (forward spread effect index) dan efek keluasan ke belakang (backward spread effect index).

Kepekaan penyebaran menunjukkan kemampuan suatu sektor untuk mendorong pertumbuhan sektor hilirnya. Indeks kepekaan penyebaran ditentukan sebagai berikut:

$$
U_{i}=\frac{\frac{1}{n} Z_{i}}{\frac{1}{n^{2}} \sum_{i=1}^{n} Z_{i}}
$$

dimana :

$U_{i}=$ indeks kepekaan penyebaran

QE Journal | Vol.04 - No.02 June 2015 - 67 
$Z_{i}=$ nilai keterkaitan langsung dan tidak langsung ke depan

Daya penyebaran menunjukkan kemampuan suatu sektor untuk menarik pertumbuhan sektor hulunya. Indeks daya penyebaran ditentukan sebagai berikut :

$$
U_{j}=\frac{\frac{1}{n} Z_{j}}{\frac{1}{n^{2}} \sum_{j=1}^{n} Z_{j}}
$$

dimana :

$\mathrm{Uj}=$ indeks daya penyebaran

$\mathrm{Zj}=$ nilai keterkaitan langsung dan tidak langsung ke belakang

Efek keluasan ke depan menunjukkan besarnya keterkaitan ke depan suatu sektor yang disebabkan oleh sejumlah kecil sektor. Indeks efek keluasan ke depan ditentukan sebagai berikut:

$$
S_{i}=\frac{V_{i}}{\sum_{i=1}^{n} \frac{V_{i}}{n}}
$$

dimana:

$\mathrm{Si}=$ indeks efek keluasan ke depan

$\mathrm{Vi}=$ koefisien variasi dari keterkaitan ke depan, yang nilainya ditentukan sebagai berikut :

$$
V_{i}=\frac{\sqrt{\left.\frac{1}{n-\sum_{i=1}^{n}} \sum_{i j}-\frac{1}{n_{i j}} \sum_{i=1}^{n} z_{i j}\right)^{2}}}{\sum_{i=1}^{n} z_{i j}}
$$

Efek keluasan ke belakang menunjukkan besarnya keterkaitan ke belakang suatu sektor yang disebabkan oleh sejumlah kecil sektor. Indeks efek keluasan ke depan ditentukan sebagai berikut :

$$
S_{j}=\frac{V_{j}}{\sum_{i=1}^{n} \frac{V_{j}}{n}}
$$

dimana :

$\mathrm{Sj}$ = indeks efek keluasan ke belakang 


$$
\begin{aligned}
& \mathrm{Vj}=\text { koefisien variasi dari keterkaitan ke belakang, yang nilainya } \\
& V j=\frac{\sqrt{\left.\frac{1}{n-1} \sum_{j=1}^{n} z_{i j}-\frac{1}{n} \sum_{j=1}^{n} z_{i j}\right)^{2}}}{\frac{1}{n} \sum_{j=1}^{n} z_{i j}}
\end{aligned}
$$

Analisis pengganda yang digunakan dalam penelitian ini adalah pengganda dengan pendekatan rata-rata $\left(M_{a}\right)$. Analisis pengganda yang menjadi fokus dalam studi ini meliputi jenis pengganda: output bruto (gross output/production multiplier), pengganda tenaga kerja (employment multiplier) dan pengganda pendapatan rumahtangga (household income multiplier).

Pengganda output bruto menunjukkan total dampak terhadap output dalam perekonomian secara keseluruhan akibat adanya peningkatan permintaan output pada suatu neraca $i$, di mana nilai pengganda ini diperoleh dari penjumlahan koefisien matriks pengganda neraca di blok sektor produksi sepanjang kolom neraca $i$.

$$
X_{j}=\sum_{i=1}^{n} \alpha_{i j}
$$

dimana :

$\mathrm{Xj}_{\mathbf{j}}=$ pengganda output bruto

$\alpha \mathrm{ij}=$ koefisien matriks pengganda neraca di blok sektor produksi

Pengganda tenaga kerja (employment multiplier) menunjukkan total dampak terhadap penyerapan tenaga kerja akibat adanya peningkatan pendapatan pada suatu neraca $i$. di mana nilai pengganda ini diperoleh dari penjumlahan koefisien matriks pengganda neraca di blok sektor produksi sepanjang kolom neraca $i$ yang terlebih dahulu dikalikan dengan koefisien teknis tenaga kerja.

$$
E_{j}=\sum_{i=1}^{n} L . \alpha_{i j}
$$

dimana :

$\mathrm{Ej} \quad=$ pengganda tenaga kerja

$\alpha \mathrm{ij}=$ koefisien matriks pengganda neraca di blok sektor produksi

$\mathrm{L}=$ koefisien matriks tenaga kerja 
Pengganda pendapatan rumahtangga (household income multiplier) menunjukkan total dampak terhadap pendapatan rumahtangga dalam perekonomian akibat adanya peningkatan pendapatan pada suatu neraca $i$, di mana nilai pengganda ini diperoleh dari penjumlahan koefisien matriks pengganda neraca yang unsur-unsurnya termasuk dalam kelompok rumahtangga sepanjang kolom neraca $i$.

$$
H_{j}=\sum_{i=1}^{n} \beta_{i j}
$$

dimana :

$\mathrm{Hj}$ = pengganda pedapatan rumahtangga

$\beta \mathrm{ij}=$ koefisien matriks pengganda neraca di blok institusi rumahtangga

Selanjutnya berdasarkan hasil rangking terhadap urutan sektor yang menempati posisi teratas sampai terbawah yang diukur dari koefisien pengganda (output bruto, tenaga kerja dan pendapatan rumahtangga) dan keterkaitan (langsung dan tidak langsung) ke depan dan ke belakang kemudian diberikan bobot di mana sektor yang menempati peringkat pertama diberikan skor tertinggi, dan seterusnya sampai pada peringkat paling rendah diberikan skor 1 . Kemudian skor untuk masing-masing sektor dijumlah berdasarkan kategorinya (pengganda dan keterkaitan) kemudian diurutkan, di mana sektor yang memiliki skor total tertinggi ditetapkan sebagai rangking pertama. Berdasarkan rangking tersebut akan diketahui bagaimana keragaan model Pembangunan Ekonomi sektor IMMT.

Berdasarkan konsep dan penelitian empiris yang telah diuraikan pada bagian sebwlumnya serta mengacu pada tujuan penelitian, dijabarkan secara flowchartmekanisme dan tahapan penelitian sebagaimana ditunjkkan pada Gambar 1.

\section{HASIL DAN PEMBAHASAN}

\section{Analisis Keterkaitan}

Keterkaitan sektor dalam studi ini dianalis berdasarkan analisis dampak penyebaran, yang ditunjukkan oleh indeks kepekaan penyebaran dan daya penyebaran, dan efek keluasan (ke depan dan ke belakang). Indeks dampak penyebaran dan efek keluasan untuk masing-masing sektor 
produksi di Propinsi Sumatera Utara tahun 2009 ditunjukkan pada Tabel1. Kemudian masing-masing sektor produksi tersebut diklasifikasikan ke dalam empat kelompok yang didasarkan dampak penyebaran ditunjukkan pada Tabel 2.Indeks dampak penyebaran merupakan nilai yang akan menjadi indikator dalam menentukan sektor-sektor mana yang dampak penyebarannya di atas atau di bawah rata-rata. Sektor yang memiliki indeks dampak penyebaran lebih dari satu menunjukkan dampak penyebaran sektor tersebut di atas rata-rata daya penyebaran secara keseluruhan, yang berarti sektor tersebut memiliki kemampuan yang cukup kuat dalam menarik/mendorong sektor hulu/hilir. Sedangkan indeks efek keluasan menunjukkan besarnya keterkaitan (ke depan dan ke belakang) suatu sektor yang disebabkan oleh sejumlah kecil sektor. Apabila indeks keluasan ke depan kurang dari satu berarti suatu sektor memiliki penjualan kepada sejumlah besar sektor, sedangkan indeks keluasan ke belakang kurang dari satu berarti suatu sektor membeli dari sejumlah besar sektor.

Berdasarkan Tabel 1terlihat, Pertama, sektor IMMT memiliki indeks kepekaan penyebaran yang lebih besar satu. Hal ini berarti sektor tersebut memiliki kemampuan yang kuat dalam mendorong sektor hilirnya. Selain itu IMMT memiliki indeks kepekaan penyebaran terbesar kedua, yaitu 1.0596. Nilai ini menunjukkan bahwa kenaikan satu unit output sektor IMMT akan menyebabkan kenaikan output sektor hilirnya sebesar 1.0596 unit.

Kedua, sektor IMMT merupakan sektor industri pengolahan yang memiliki indeks daya penyebaran yang lebih besar satu, dimana sektor ini memiliki indeks daya penyebaran yang terbesar, yaitu 2.6974. Dan, Ketiga, Dan dari sisi indeks efek keluasan, terutama efek keluasan ke belakang, IMMT memiliki angka terbesar pertama. Hal ini apabila dibandingkan dengan sektor-sektor lainnya, IMMT merupakan sektor yang memiliki keterkaitan dengan sejumlah besar sektor hulunya. 
Tabel 1. Indeks Dampak Penyebaran dan Efek Keluasan Sektor Produksi Di Provinsi Sumut Tahun 2009

\begin{tabular}{|c|c|c|c|c|}
\hline Sektor & KP & DP & KD & KB \\
\hline Tanaman bahan makanan & 0,9406 & 1,7430 & 0,2432 & 0,2909 \\
\hline Tanaman perkebunan & 0,9528 & 1,2461 & 0,2487 & 0,2671 \\
\hline Peternakan & 0,9748 & 1,0619 & 0,2565 & 0,2447 \\
\hline Kehutanan & 0,9584 & 0,6380 & 0,2352 & 0,2145 \\
\hline Perikanan & 0,9536 & 0,7705 & 0,2418 & 0,2218 \\
\hline Penambangan migas dan penggalian & 0,9774 & 0,7849 & 0,2396 & 0,2348 \\
\hline Ind, makanan, minuman dan tembakau & 1,0596 & 2,6974 & 0,3075 & 0,4505 \\
\hline Ind, pmintlan, pkaian jadi,brg dr kulit & 0,9813 & 1,3703 & 0,3055 & 0,3231 \\
\hline Ind, kayu, brg dari kayu,rotan, bambu & 1,0253 & 1,0037 & 0,2658 & 0,2561 \\
\hline Ind, kertas, brg dr kertas, percetakan & 0,9228 & 0,7777 & 0,2460 & 0,2322 \\
\hline Ind, kimia dsr, ppuk,jamu, brg dr karet & 1,0129 & 1,7253 & 0,3017 & 0,3424 \\
\hline Ind, pengilangan migas & 1,1275 & 0,5684 & 0,2537 & 0,2067 \\
\hline Ind, keramik, kaca, bahan bkn logam & 1,0130 & 0,7606 & 0,2441 & 0,2192 \\
\hline Ind, logam dasar, besi dan baja & 1,0280 & 0,8822 & 0,2775 & 0,2624 \\
\hline Ind, pengangkutan,mesin, dan alatnya & 0,9666 & 1,0066 & 0,2812 & 0,2781 \\
\hline Ind, barang-barang lainnya & 1,0538 & 0,5063 & 0,2407 & 0,2031 \\
\hline Listrik, gas dan air minum & 0,9449 & 0,9848 & 0,2399 & 0,2362 \\
\hline Bangunan/konstruksi & 1,0149 & 1,4695 & 0,2548 & 0,2841 \\
\hline Perdagangan & 0,8967 & 1,7767 & 0,2449 & 0,3155 \\
\hline Restoran dan hotel & 1,0481 & 0,8571 & 0,2550 & 0,2245 \\
\hline Jasa angkutan jalan raya, kereta api & 0,9574 & 0,8343 & 0,2399 & 0,2258 \\
\hline Jasa angkutan laut, danau, sungai & 1,0570 & 0,4840 & 0,2416 & 0,2029 \\
\hline Jasa angkutan udara & 1,0342 & 0,4560 & 0,2390 & 0,2022 \\
\hline Jasa penunjang angkutan & 1,0297 & 0,6102 & 0,2441 & 0,2141 \\
\hline Komunikasi & 1,0142 & 0,6808 & 0,2423 & 0,2152 \\
\hline Bank dan lembaga keuangan Lain & 0,9848 & 0,7983 & 0,2421 & 0,2235 \\
\hline Usaha sewa bangunan dan tanah & 0,9822 & 0,8199 & 0,2410 & 0,2221 \\
\hline Jasa perusahaan & 1,0672 & 0,5409 & 0,2415 & 0,2053 \\
\hline Pemerintahan & 1,0202 & 1,1447 & 0,2548 & 0,2535 \\
\hline
\end{tabular}

Sumber : SAM Propinsi Sumut Tahun 2009 (Diolah)

Keterangan :

$\begin{array}{lll}\mathrm{KP} & =\text { kepekaan penyebaran } & \mathrm{KD}=\text { efek keluasan ke depan } \\ \mathrm{DP} & =\text { daya penyebaran } & \mathrm{KB}=\text { efek keluasan ke belakang }\end{array}$

Berdasarkan Tabel 2 terlihat sektor IMMT memiliki indeks kepekaan dan daya penyebaran lebih besar dari satu sekaligus. Hal ini berarti sektor tersebut memiliki peran besar dalam kaitannya dengan sektor hulu dan hilirnya. 
Tabel 2. Klasifikasi Indeks Dampak Penyebaran Sektor Produksi Di Provinsi Sumut 2009 Menurut Empat Kelompok

\begin{tabular}{|c|c|c|c|}
\hline & \multicolumn{2}{|c|}{ Kepekaan Penyebaran } \\
\hline & & $>1$ & $<1$ \\
\hline \multirow[b]{2}{*}{ 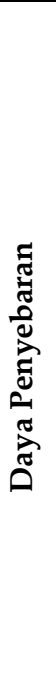 } & $>1$ & $\begin{array}{l}\text { Ind, makanan, minuman dan tembakau } \\
\text { Ind, kayu, brg dari kayu,rotan, bambu } \\
\text { Ind, kimia dsr, ppuk,jamu, brg dr karet } \\
\text { Bangunan/konstruksi } \\
\text { Pemerintahan }\end{array}$ & $\begin{array}{l}\text { Tanaman perkebunan } \\
\text { Tanaman bahan makanan } \\
\text { Peternakan } \\
\text { Ind, pmintlan, pkaian jadi,brg dr kulit } \\
\text { Ind, pengangkutan,mesin, dan alatnya } \\
\text { Perdagangan }\end{array}$ \\
\hline & $<1$ & $\begin{array}{l}\text { Ind, pengilangan migas } \\
\text { Ind, barang-barang lainnya } \\
\text { Ind, logam dasar, besi dan baja } \\
\text { Ind, keramik, kaca, bahan bkn logam } \\
\text { Restoran dan hotel } \\
\text { Jasa angkutan udara } \\
\text { Jasa penunjang angkutan } \\
\text { Komunikasi }\end{array}$ & $\begin{array}{l}\text { Kehutanan } \\
\text { Perikanan } \\
\text { Ind, kertas, brg dr kertas, percetakan } \\
\text { Bank dan lembaga keuangan Lain } \\
\text { Usaha sewa bangunan dan tanah } \\
\text { Penambangan migas dan penggalian } \\
\text { Listrik, gas dan air minum } \\
\text { Bangunan/konstruksi } \\
\text { Listrik, gas dan air minum } \\
\text { Jasa angkutan laut, danau, sungai } \\
\text { Komunikasi }\end{array}$ \\
\hline
\end{tabular}

Sumber : SAM Propinsi Sumut Tahun 2009 (Diolah)

Berdasarkan analisis di atas dapat dinyatakan bahwa sektor IMMTmemiliki peran besar dalam perekonomian provinsi Sumatera Utara ditinjau dari keterkaitannya. Hal ini terbukti dengan dominannya sektor industri pengolahan dan sektor lainnya yang memiliki indeks kepekaan dan daya penyebaran yang lebih besar dari satu serta efek

keluasan ke depan dan kebelakang kurang yang lebih besar dari sektorsektor lainnya.

\section{Analisis Pengganda}

Sebagaimana telah dikemukakan pada bab sebelumnya, analisis tentang pengganda produksi menyangkut 3 (Tiga) jenis koefesien pengganda, yaitu pengganda output bruto (gross output/production multiplier), pengganda tenaga kerja (employment multiplier) dan pengganda pendapatan rumahtangga (household income multiplier). Kedua koefesien pengganda untuk masing-masing sektor produksi, yaitu: pengganda output bruto dan 
tenaga kerja di Propinsi Sumatera Utara tahun 2009, ditunjukkan pada Tabel 3, sedangkan untuk pengganda pendapatan rumahtangga ditunjukkan pada Tabel 4.

Tabel 3. Koefisien Pengganda Output Bruto dan Tenaga Kerja Menurut Sektoral di Propinsi Sumatera Utara Tahun 2009

\begin{tabular}{lcc}
\hline Sektor & Output Bruto & Tenaga Kerja \\
\hline Tanaman bahan makanan & 3,9701 & 1,0199 \\
Tanaman perkebunan & 4,0214 & 1,1099 \\
Peternakan & 4,1145 & 0,9404 \\
Kehutanan & 4,0451 & 0,9701 \\
Perikanan & 4,0251 & 1,0071 \\
Penambangan migas dan penggalian & 4,1254 & 1,0236 \\
Industri Makanan, Minuman \& Tembakau & $\mathbf{4 , 4 7 2 1}$ & $\mathbf{0 , 9 8 0 6}$ \\
Ind. pmintlan, pkaian jadi,brg dari kulit & 4,1416 & 0,8909 \\
Ind. kayu, brg dari kayu,rotan, bambu & 4,3277 & 0,9810 \\
Ind. kertas, brg dr kertas, percetakan & 3,8948 & 0,7895 \\
Ind. kimia dsr, ppuk,jamu,brg dr karet & 4,2753 & 0,9230 \\
Ind. pengilangan migas & 4,7591 & 1,0224 \\
Ind. keramik, kaca, bahan bkn logam & 4,2758 & 0,9441 \\
Ind. logam dasar, besi dan baja & 4,3389 & 0,9383 \\
Ind. pengangkutan, mesin, dan alatnya & 4,0797 & 0,9051 \\
Ind. barang-barang lainnya & 4,4481 & 0,9574 \\
Listrik, gas dan air minum & 3,9884 & 0,9518 \\
Bangunan/konstruksi & 4,2836 & 1,0179 \\
Perdagangan & 3,7848 & 1,0060 \\
Restoran dan hotel & 4,4239 & 0,9872 \\
Jasa angkutan jalan raya, kereta api & 4,0410 & 1,0195 \\
Jasa angkutan laut, danau, sungai & 4,4612 & 1,0046 \\
Jasa angkutan udara & 4,3650 & 0,9623 \\
Jasa penunjang angkutan & 4,3463 & 1,0308 \\
Komunikasi & 4,2806 & 1,0525 \\
Bank dan lembaga keuangan Lain & 4,1566 & 1,0527 \\
Usaha sewa bangunan dan tanah & 4,1457 & 1,0077 \\
Jasa perusahaan & 4,5046 & 1,0475 \\
Jasa Pemerintahan & 4,3059 & 1,3085 \\
\hline Sumber : SAM Propinsi Sumat
\end{tabular}

Sumber : SAM Propinsi Sumatera Utara Tahun 2009 (Diolah)

Berdasarkan Tabel 3 menunjukkan, Pertama, koefisien pengganda output bruto dari sektor industri pengolahan di Propinsi Sumatera Utara berkisar 3.97-4.47. Dari sektor ini, IMMT adalah sektor dengan koefisien terbesar kedua, yaitu sebesar 4.4721. Hal ini berarti total dampak terhadap output dalam perekonomian secara keseluruhan sebesar 4.4721 kali akibat adanya 
peningkatan permintaan output pada sektor IMMT sebesar 1 satuan. Dan Kedua, koefisien pengganda tenaga kerja dari sektor industri pengolahan berkisar 0.79-1.01. Dari sektor ini, IMMT merupakan sektor dengan koefisien terbesar ketiga, namun tidak demikian posisinya ditinjua dari keseluruhan sektor.

Koefisien pengganda pendapatan rumahtangga di Propinsi Sumatera Utara pada tahun 2009 diperlihatkan pada Tabel 4. Dari Tabel4 terlihat, Pertama, koefisien pengganda pendapatan rumahtangga dari sektor industri pengolahan di Propinsi Sumatara Utara berkisar 1.20-1.57. Dari sektor ini terlihat IMMT merupakansektor dengan koefisien terbesar keduaKedua, kelompok rumahtangga yang paling besar menerima peningkatan pendapatan akibat injeksi dari sektor industri pengolahan, pertanian dan sektor lainnya adalah golongan atas di kota.

Berdasarkan hasil analisis sebagaimana diuraikan pada Tabel 3, 4 dan Keterkaitan dapat diuraikan dengan jelas urutan sektor yang menempati posisi teratas sampai terbawah apabila dilakukan rangking. Tabel 5 menunjukkan hasil rangking masing-masing sektor tersebut. Kolom total dari tabel tersebut menunjukkan rangking akhir dari masing-masing sektor. Dari kolom total Tabel 5 menunjukkan IMMT sebagai sektor yang menempati rangking keenam di PropinsiSumatera Utara. Berdasarkan hasil temuan tersebut dapat dinyatakan bahwa sektor ini merupakan salah satu dikatakan sebagai sektor yang potensial.

Keberadaan sektor potensial tersebut yang menjadi tulang punggung struktur perekonomian di Sumatera Utara tidak terlepas dari kebijakan yang dibuat oleh pemerintah daerah setempat. Berdasarkan pola dasar pembangunan Propinsi Sumatera Utara terlihat bahwa, selain peningkatan mutu sumberdaya manusia, prioritas pembangunan pada periode 2009 ke depan adalah mengembangkan industri, terutama pada sektor IMMT yang maju yang didukung oleh pertanian yang tangguh serta bidang pembangunan lainnya. 
Tabel 4. Koefisien Pengganda Pendapatan Rumahtangga Menurut Golongan Rumahtangga Propinsi Sumatera Utara Tahun 2009

\begin{tabular}{|c|c|c|c|c|c|c|c|}
\hline Sektor & $\begin{array}{c}\text { Buruh } \\
\text { Tani }\end{array}$ & $\begin{array}{c}\text { Pengusaha } \\
\text { Pertanian }\end{array}$ & $\begin{array}{c}\text { Gol. } \\
\text { Rendah } \\
\text { Di } \\
\text { Desa } \\
\end{array}$ & $\begin{array}{c}\text { Gol. } \\
\text { Atas } \\
\text { Di } \\
\text { Desa } \\
\end{array}$ & $\begin{array}{c}\text { Gol. } \\
\text { Rendah } \\
\text { Di } \\
\text { Kota } \\
\end{array}$ & $\begin{array}{c}\text { Gol. } \\
\text { Atas } \\
\text { Di } \\
\text { Kota } \\
\end{array}$ & Total \\
\hline Tanaman bahan makanan & 0.1626 & 0.1605 & 0.1701 & 0.1007 & 0.1235 & 0.1763 & 0.8936 \\
\hline Tanaman perkebunan & 0.2353 & 0.1655 & 0.1665 & 0.0979 & 0.1182 & 0.1836 & 0.9670 \\
\hline Peternakan & 0.2277 & 0.1617 & 0.1688 & 0.0973 & 0.1271 & 0.1921 & 0.9746 \\
\hline Kehutanan & 0.1369 & 0.1495 & 0.1632 & 0.0972 & 0.1206 & 0.1717 & 0.8389 \\
\hline Perikanan & 0.1550 & 0.1503 & 0.1621 & 0.0954 & 0.1206 & 0.1726 & 0.8559 \\
\hline Penambangan migas dan penggalian & 0.0437 & 0.1326 & 0.1707 & 0.1066 & 0.1349 & 0.1961 & 0.7845 \\
\hline Ind. Makanan, Minuman \& Tembakau & 0.0966 & 0.1205 & 0.1547 & 0.0832 & 0.1431 & 0.1825 & 0.7806 \\
\hline Ind. Tekstil, P. Jadi, Kulit \& A. Kaki & 0.0387 & 0.0943 & 0.1448 & 0.0742 & 0.1521 & 0.1841 & 0.6881 \\
\hline Ind. Kayu, Bambu, Rotan \& Furnitur & 0.0306 & 0.0726 & 0.1080 & 0.0566 & 0.1099 & 0.1349 & 0.5125 \\
\hline Ind. Kertas, Percetakan \& Penerbitan & 0.0421 & 0.0999 & 0.1600 & 0.0802 & 0.1742 & 0.2101 & 0.7665 \\
\hline Ind. Kimia, B.Kimia, Kertas \& Plastik & 0.0419 & 0.0957 & 0.1427 & 0.0741 & 0.1465 & 0.1785 & 0.6793 \\
\hline Ind. Pengilangan Minyak Bumi & 0.0437 & 0.1273 & 0.1739 & 0.0998 & 0.1562 & 0.2046 & 0.8054 \\
\hline Ind. Barang Mineral Bukan Logam & 0.0329 & 0.0833 & 0.1299 & 0.0666 & 0.1374 & 0.1673 & 0.6173 \\
\hline Ind. Logam Dasar \& B.Jadi Logam & 0.0383 & 0.0987 & 0.1497 & 0.0774 & 0.1551 & 0.1880 & 0.7072 \\
\hline Ind. Pengolahan Lainnya & 0.0475 & 0.0963 & 0.1467 & 0.0737 & 0.1560 & 0.1866 & 0.7068 \\
\hline Listrik, Gas \& Air Bersih & 0.0386 & 0.1097 & 0.1477 & 0.0925 & 0.1205 & 0.1805 & 0.6895 \\
\hline Bangunan/Kontruksi & 0.0435 & 0.0975 & 0.1550 & 0.0969 & 0.1417 & 0.2263 & 0.7609 \\
\hline Perdagangan, Hotel \& Restoran & 0.0492 & 0.1225 & 0.1729 & 0.1114 & 0.1419 & 0.2287 & 0.8266 \\
\hline Pengangkutan \& Komunikasi & 0.0436 & 0.1098 & 0.1592 & 0.1017 & 0.1344 & 0.2151 & 0.7637 \\
\hline Keuangan, Persewaan \& J. Perusahaan & 0.0441 & 0.1203 & 0.1655 & 0.1057 & 0.1347 & 0.2106 & 0.7809 \\
\hline Jasa-Jasa & 0.0649 & 0.1234 & 0.2148 & 0.1476 & 0.1880 & 0.3553 & 1.0939 \\
\hline
\end{tabular}

Keterangan: Pengusaha Pertanian merupakan agregat dari rumahtangga Petani Lahan Sempit dan Luas

Sumber: SAM Propinsi Sumatera Utara Tahun 2009 (Diolah) 
Tabel 5. Rangking Sektoral di PropinsiSumater Utara Tahun 2009

\begin{tabular}{|c|c|c|c|c|c|c|}
\hline & \multicolumn{6}{|c|}{ Rangking } \\
\hline & \multirow[b]{2}{*}{$\begin{array}{l}\text { Outpu } \\
\text { t } \\
\text { Bruto }\end{array}$} & \multicolumn{2}{|c|}{ Keterkaitan } & \multirow[b]{2}{*}{$\begin{array}{l}\text { Tenag } \\
\text { a kerja }\end{array}$} & \multirow[b]{2}{*}{$\begin{array}{c}\text { Penda } \\
\text { patan } \\
\text { RT }\end{array}$} & \multirow[b]{2}{*}{ Tota } \\
\hline & & $\begin{array}{c}\text { Ke } \\
\text { Belaka } \\
\text { ng }\end{array}$ & $\begin{array}{c}\text { Ke } \\
\text { Depan }\end{array}$ & & & \\
\hline Tanaman bahan makanan & 27 & 27 & 3 & 9 & 6 & 14 \\
\hline Tanaman perkebunan & 25 & 25 & 7 & 2 & 2 & 5 \\
\hline Peternakan & 20 & 20 & 9 & 24 & 22 & 26 \\
\hline Kehutanan & 22 & 22 & 23 & 19 & 14 & 28 \\
\hline Perikanan & 24 & 24 & 20 & 13 & 13 & 21 \\
\hline $\begin{array}{l}\text { Penambangan migas dan } \\
\text { penggalian }\end{array}$ & 19 & 19 & 18 & 7 & 5 & 3 \\
\hline $\begin{array}{l}\text { Industri Makanan, Minuman \& } \\
\text { Tembakau }\end{array}$ & 3 & 3 & 1 & 18 & 17 & 6 \\
\hline $\begin{array}{l}\text { Ind. pmintlan, pkaian jadi,brg dari } \\
\text { kulit }\end{array}$ & 18 & 18 & 6 & 28 & 28 & 22 \\
\hline $\begin{array}{l}\text { Ind. kayu, brg dari kayu,rotan, } \\
\text { bambu }\end{array}$ & 10 & 10 & 11 & 17 & 20 & 19 \\
\hline $\begin{array}{l}\text { Ind. kertas, brg dr kertas, } \\
\text { percetakan } \\
\text { Ind. kimia dsr, ppuk,jamu,brg dr }\end{array}$ & 28 & 28 & 19 & 29 & 29 & 29 \\
\hline karet & 15 & 15 & 4 & 26 & 26 & 15 \\
\hline Ind. pengilangan migas & 1 & 1 & 25 & 8 & 10 & 8 \\
\hline $\begin{array}{l}\text { Ind. keramik, kaca, bahan bkn } \\
\text { logam }\end{array}$ & 14 & 14 & 21 & 23 & 21 & 20 \\
\hline Ind. logam dasar, besi dan baja & 9 & 9 & 13 & 25 & 25 & 24 \\
\hline $\begin{array}{l}\text { Ind. pengangkutan,mesin, dan } \\
\text { alatnya }\end{array}$ & 21 & 21 & 10 & 27 & 27 & 23 \\
\hline Ind. barang-barang lainnya & 5 & 5 & 27 & 21 & 23 & 27 \\
\hline Listrik, gas dan air minum & 26 & 26 & 12 & 22 & 24 & 25 \\
\hline Bangunan/konstruksi & 12 & 12 & 5 & 11 & 18 & 17 \\
\hline Perdagangan & 29 & 29 & 2 & 14 & 9 & 11 \\
\hline Restoran dan hotel & 6 & 6 & 14 & 16 & 16 & 16 \\
\hline Jasa angkutan jalan raya, kereta api & 23 & 23 & 15 & 10 & 12 & 12 \\
\hline Jasa angkutan laut, danau, sungai & 4 & 4 & 28 & 15 & 15 & 13 \\
\hline Jasa angkutan udara & 7 & 7 & 29 & 20 & 19 & 18 \\
\hline Jasa penunjang angkutan & 8 & 8 & 24 & 6 & 7 & 9 \\
\hline Komunikasi & 13 & 13 & 22 & 4 & 4 & 10 \\
\hline Bank dan lembaga keuangan Lain & 16 & 16 & 17 & 3 & 3 & 4 \\
\hline Usaha sewa bangunan dan tanah & 17 & 17 & 16 & 12 & 11 & 7 \\
\hline Jasa perusahaan & 2 & 2 & 26 & 5 & 8 & 2 \\
\hline Jasa Pemerintahan & 11 & 11 & 8 & 1 & 1 & 1 \\
\hline
\end{tabular}

QE Journal | Vol.04 - No.02 June 2015 - 77 


\section{SIMPULAN DAN SARAN}

Berdasarkan hasil analisis yang telah diuraikan pada bab-bab sebelumnya, maka dapat ditarik beberapa simpulan sebagai berikut berikut:

1. Sektor Industri Makanan, Minuman dan Tembakau (IMMT) memiliki indeks kepekaan penyebaran yang lebih besar satu dan terbesar kedua.

2. Sektor IMMT merupakan sektor industri pengolahan yang memiliki indeks daya penyebaran yang lebih besar satu, dimana sektor ini memiliki indeks daya penyebaran yang terbesar

3. Dari sisi indeks efek keluasan, terutama efek keluasan ke belakang, IMMT memiliki angka terbesar pertama.

4. Berdasarkan pengganda output IMMT adalah sektor dengan koefisien terbesar kedua, akan tetapi tidak demikian posisinya apabila ditinjau dari pengganda tenaga kerja.

5. Dalam kontribusinya terhadap pengganda pendapatan, IMMT memberikan kontribusi terbesar pada pendapatan rumahtangga golongan atas di kota.

6. Merujuk kepada peringkat secara total, IMMT berada pada peringkat enam.

Berdasarkan temuan penelitian ini menunjukkan bahwa dari kelompok enam besar sektor IMMT yang memperlihatkan peran besar di Sumatera Utara tahun 2009. Dengan demikian sektor tersebut merupakan salah satu sektor pemimpin (leading sector). Hal ini memberikan implikasi bahwa dalam memacu pertumbuhan ekonomi yang diiringi dengan pemerataan pendapatan di propinsi Sumatera Utara ke depan hendaknya diprioritaskan kepada sektor IMMT.

Berdasarkan karakteristiknya, Industri Makanan, Minuman dan Tembakau merupakan sektor yang dikategorikan sebagai agroindustri. Oleh karena itu strategi agroindustrialisasi (agroindustrialization strategy) merupakan pilihan strategi kebijakan industrialisasi yang tepat diterapkan guna mewujudkan perekonomian Sumatera Utara yang tangguh di masa mendatang. Senada dengan hasil studi Tambunan (1992), Daryanto (1999) dan Benerjee dan Siregar (2002) menyatakan bahwa pengembangan 
agroindustri, yaitu industri yang berbasis pertanian, memberikan peranan yang besar dalam perekonomian.

\section{DAFTAR PUSTAKA}

Arndt, C., H.T. Jensen and F. Tarp.1998. Structural Characteristics of the Economy of Mozambique: SAM Based Analysis (http://www.econ.ku.dk/derg/papers/ article.pdf)

Bautista, S. Robinson and M. Said.1999. Alternative Industrial Development Paths for Indonesia: SAM and CGE Analysis. International Food Policy Institute, Washington, DC.

Banerjee, S dan H. Siregar. 2002. Agriculture As The Leading'Sektor. UNSFIR Working Paper 02/02, UNSFIR, Jakarta.

BPS Sumatera Utara. 2012. Sumatera Utara dalam Angka 2011. Biro Pusat Statistik Propinsi Sumatera Utara, Medan.

Daryanto, A. 1995. Applications of Input-Output Analysis. Departement of Socio-Economic Sciences Faculty of Agriculture, Bogor. . 1999. Structural Change and Determinants of Agriculture's Relative

Decline. Mimbar Sosek : Journal of Agricultural and Resource SocioEconomics, 12 (3): 75-94.

Hafrizianda. 2007. Dampak Pembangunan Sektor Pertanian Terhadap Distribusi Pendapatan dan Perekonomian Regional Provinsi Papua: Suatu Analisis Model Sistem Neraca Sosial Ekonomi. Disertasi Doktor. Program Pascasarjana, Institut Pertanian Bogor, Bogor.

Jhingan, M.L. 2003. Ekonomi Pembangunan dan Perencanaan (Terjemahan). PT. Raja Grafindo Persada, Jakarta.

Nazara, Suahasil. 1997. Analisis Input-Output. Lembaga Penerbit Fakultas Ekonomi Universitas Indonesia, Jakarta.

Nafziger E. Wayne. 1997, The Economics Of Developing Countries, Prentice Hall.

Nugrahadi. 2007. Analisis Pola Perubahan Struktural dan Sumber-Sumber Pertumbuhan dalam Ekonomi Jawa Barat. Makalah pendamping disampaikan dalam seminar internasional oleh Program Pascasarjana 
UNAS Jakarta dan National University of Malaysia, 11-12 November 2007.

2007. Keterkaitan (Linkage) Sektor-Sektor Ekonomi Jawa Barat. Jurnal Ilmu dan Budaya UNAS Jakarta, volume 28, no. 7, Agustus 2007.

2007. Dampak Investasi pada Sektor-Sektor Ekonomi Unggulan Terhadap Penyerapan Tenaga Kerja di Sumatera Utara. Makalah Disajikan pada "Seminar Nasional dengan Tema: Lampu Kuning Pertumbuhan Penduduk"Kerjasama PUSDIBANG-KS UNIMED dan BKKBN-SU, Medan, 11 Desember.

2007. Pemberdayaan Ekonomi Rakyat dan Masalah Kemiskinan di Provinsi Sumatera Utara. Makalah disampaikandalam Diskusi Ilmiah Di Sekolah Pascasarjana UNIMED, Medan, 28 November.

. 2008. Analisis Sumber Pertumbuhan, Keterkaitan dan Distribusi Pendapatan dalam Proses Perubahan Struktural Ekonomi Provinsi Jawa Barat. Disertasi Doktor. Program Pascasarjana, Institut Pertanian Bogor, Bogor.

2013. Keragaan Model Kebijakan Pembangunan Ekonomi Sektoral Di Sumatera Utara. Quantitative Economics Journal, Volume 02. No. 01, Maret 2013

Robinson, S., A. Cattaneo and M. El-Said. 1998. Estimating a Social Accounting Matrix Using Cross Entropy Methods. TMD Discussion Paper No. 33, International Food Policy Research Institute.

Sadoulet, E. and A. de Janvry. 1995. Quantitative Development Analysis. The Johns Hopkins University Press, Baltimore.

Thorbecke. 2001. The Social Accounting Matrix: Deterministic or Stochastic Concept? Paper prepared for a conference in Honor of Graham Pyatt's retirement, at the Institute of Social Studies, The Hague, Netherlands, November 29 and 30, 2001.

Todaro. 2000. Economic Development. Seventh Edition. Pearson Education Liminited, New York.

Todaro dan Smith. 2011. Pembangunan Ekonomi, Edisi Kesebelas, Jilid 1. Penerbit Erlangga, Jakarta.

QE Journal | Vol.04 - No.02 June 2015 - 80 
Lampiran:

Tabel 4.1.Klasifikasi SAM provinsi Sumatera Utara (53 sektor)

\begin{tabular}{|c|c|c|c|}
\hline \multicolumn{3}{|r|}{ Uraian } & Kode \\
\hline \multirow{3}{*}{ Faktor Produksi } & \multicolumn{2}{|c|}{ T.K.Penerima Upah dan Gaji } & 1 \\
\hline & \multicolumn{2}{|c|}{ T.K.Bukan Penerima Upah dan Gaji } & 2 \\
\hline & \multicolumn{2}{|l|}{ Kapital } & 3 \\
\hline \multirow{15}{*}{ Institusi } & \multirow{7}{*}{ Rumahtangga } & Buruh Tani & 4 \\
\hline & & Petani Lahan Sempit atau < $1.0 \mathrm{Ha}$ & 5 \\
\hline & & Petani Lahan Luas atau $\geq 1.0 \mathrm{Ha}$ & 6 \\
\hline & & Pendapatan Golongan Rendah di Desa & 7 \\
\hline & & Pendapatan Golongan Atas di Desa & 8 \\
\hline & & Pendapatan Golongan Rendah di Kota & 9 \\
\hline & & Pendapatan Golongan Atas di Kota & 10 \\
\hline & \multicolumn{2}{|l|}{ Perusahaan } & 11 \\
\hline & \multirow{7}{*}{ Pemerintah } & Pengeluaran Belanja Pegawai & 12 \\
\hline & & Pengeluaran Belanja Barang & 13 \\
\hline & & Pengeluaran Belanja Subsidi & 14 \\
\hline & & Pengeluaran Bidang Ekonomi & 15 \\
\hline & & Pengeluaran Bidang Pemb.Daerah & 16 \\
\hline & & Pengeluaran Bidang Pelayanan Umum & 17 \\
\hline & & & 18 \\
\hline & \multicolumn{2}{|c|}{ Tanaman bahan makanan } & 19 \\
\hline & \multicolumn{2}{|c|}{ Tanaman perkebunan } & 20 \\
\hline & \multicolumn{2}{|c|}{ Peternakan } & 21 \\
\hline & \multicolumn{2}{|l|}{ Kehutanan } & 22 \\
\hline & \multicolumn{2}{|l|}{ Perikanan } & 23 \\
\hline & \multicolumn{2}{|c|}{ Penambangan migas dan penggalian } & 24 \\
\hline & \multicolumn{2}{|c|}{ Ind. makanan, minuman dan tembakau } & 25 \\
\hline & \multicolumn{2}{|c|}{ Ind. pmintlan, pkaian jadi,brg dr kulit } & 26 \\
\hline & \multicolumn{2}{|c|}{ Ind. kayu, brg dari kayu,rotan, bambu } & 27 \\
\hline & \multicolumn{2}{|c|}{ Ind. kertas, brg dr kertas, percetakan } & 28 \\
\hline & \multicolumn{2}{|c|}{ Ind. kimia dsr, ppuk,jamu,brg dr karet } & 29 \\
\hline Sektor Produksi & \multicolumn{2}{|c|}{ Ind. pengilangan migas } & 30 \\
\hline Sektor ProduksI & \multicolumn{2}{|c|}{ Ind. keramik, kaca, bahan bkn logam } & 31 \\
\hline & \multicolumn{2}{|c|}{ Ind. logam dasar, besi dan baja } & 32 \\
\hline & \multicolumn{2}{|c|}{ Ind. pengangkutan,mesin, dan alatnya } & 33 \\
\hline & \multicolumn{2}{|c|}{ Ind. barang-barang lainnya } & 34 \\
\hline & \multicolumn{2}{|c|}{ Listrik, gas dan air minum } & 35 \\
\hline & Bangunan/kons & & 36 \\
\hline & Perdagangan & & 37 \\
\hline & Restoran dan $\mathrm{h}$ & & 38 \\
\hline & Jasa angkutan & raya, kereta api & 39 \\
\hline & Jasa angkutan & danau, sungai & 40 \\
\hline & Jasa angkutan & & 41 \\
\hline & Jasa penunjang & kutan & 42 \\
\hline
\end{tabular}

QE Journal | Vol.04 - No.02 June 2015 - 81 


\begin{tabular}{|c|c|}
\hline Uraian & Kode \\
\hline Komunikasi & 43 \\
\hline Bank dan lembaga keuangan Lain & 44 \\
\hline Usaha sewa bangunan dan tanah & 45 \\
\hline Jasa perusahaan & 46 \\
\hline Jasa Pemerintahan & 47 \\
\hline Pajak Tidak Langsung & 48 \\
\hline Anggaran Ruitn Pemda & 49 \\
\hline Anggaran Pembangunan Pemda & 50 \\
\hline Anggaran Dekonsentrasi & 51 \\
\hline Neraca Kapital & 52 \\
\hline Neraca Luar Negeri & 53 \\
\hline
\end{tabular}

QE Journal | Vol.04 - No.02 June 2015 - 82 